\title{
Synthesis, characterization and crystal structures of 2,4-di(2-aminopyridine)-6-methypyrimidine (dapmp), $\left[\mathrm{Cu}(\right.$ dapmp $\left.) \mathrm{Cl}_{2}\right]$ and $\left[\mathrm{Cu}(\right.$ dapmp $\left.)\left(\mathrm{CH}_{3} \mathrm{COO}\right)_{2}\right] \cdot \mathrm{H}_{2} \mathrm{O}$
}

\author{
Hai-Rui Ma ${ }^{\text {a }}$, Yao-Yu Wang ${ }^{\text {a,*, }}$ Ping Liu ${ }^{\text {a }}$, Dong-Sheng Li ${ }^{\text {a }}$, Qi-Zhen Shi ${ }^{\text {a }}$, \\ Gene-Hsiang Lee ${ }^{b}$, Shie-Ming Peng ${ }^{b}$ \\ ${ }^{a}$ Department of Chemistry, Shaanxi Key Laboratory of Physico-inorganic Chemistiy, Northwest University, Xi'an 710069, PR China \\ ${ }^{\mathrm{b}}$ Department of Chemistry, National Taiwan University, Taipei, Taiwan
}

Received 6 September 2004; accepted 3 November 2004

Available online 25 December 2004

\begin{abstract}
The new ligand dapmp (1) has been synthesized and the reactions of $\mathrm{CuCl}_{2} \cdot 2 \mathrm{H}_{2} \mathrm{O}$ and $\mathrm{Cu}\left(\mathrm{CH}_{3} \mathrm{COO}\right)_{2} \cdot \mathrm{H}_{2} \mathrm{O}$ with the new ligand in methanol afforded two crystalline polymorphic forms: $\left[\mathrm{Cu}(\right.$ dapmp $\left.) \mathrm{Cl}_{2}\right](\mathbf{2})$ and $\left[\mathrm{Cu}(\mathrm{dapmp})\left(\mathrm{CH}_{3} \mathrm{COO}\right)_{2}\right] \cdot \mathrm{H}_{2} \mathrm{O}(3)$, where dapmp = 2,4-di(2-aminopyridine)-6-methylpyrimidine. Single crystal X-ray diffraction showed that (1) and (2) are each connected by hydrogen bonding to form a one-dimensional supermolecular compound and (3) is connected by hydrogen bonding to form a three-dimensional supermolecular compound.
\end{abstract}

(c) 2004 Elsevier Ltd. All rights reserved.

Keywords: New ligand; Copper(II) complex; Cystal structure; One-dimensional supermolecular; Three-dimensional supermolecular; Hydrogen bonds

\section{Introduction}

In recent years, the synthesis of multidentate N-donor ligands has attracted considerable interest [1,2], mainly because they can be used to design multinuclear metal compounds, coordination polymers and supermolecular compounds, which play a very important role in biological systems, magnetic materials, electronic materials, optical materials and other fields [3-7]. In the present paper, we describe a new multidentate N-donor ligand 2,4-di(2-aminopyridine)-6-methylpyrimidine (dapmp), which can exhibit several coordination modes: anti-anti-anti-anti, syn-synsyn-syn, anti-syn-syn-anti, anti-syn-syn-syn and syn-syn-syn-anti (see Scheme 1).

\footnotetext{
${ }^{*}$ Corresponding author. Tel.: +86 29 88303097; fax: +86 29 88373398.

E-mail address: wyaoyu@nwu.edu.cn (Y.-Y. Wang).
}

Herein we report the anti-anti-anti-anti configuration of dapmp, in which the chain is formed by hydrogen bonding. The crystal structures of its copper(II) complexes with the all-anti conformation of the chelating ligand are presented.

\section{Experimental}

\subsection{Materials and physical measurements}

All reagents were commercial grade and were used as received. Infrared spectra on $\mathrm{KBr}$ pellets were recorded on a Nicolet 170SX FT-IR spectrophotometer in the range 4000-400 $\mathrm{cm}^{-1}$. NMR spectra were recorded using a VARIAN INOVA400MHZ spectrometer. Electronic spectra were recorded on a Cary 300 Bio UV-visible spectrophotometer. Elemental analyses were determined with a Perkin-Elmer model $240 \mathrm{C}$ instrument. FAB-MS 
<smiles></smiles>

1 anti-anti-anti-anti

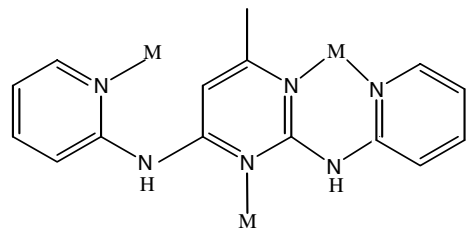

3 anti-syn-syn-anti<smiles></smiles><smiles></smiles>

2 syn-syn-syn-syn<smiles></smiles>

4 anti-syn-syn-syn

5 syn-syn-syn-anti

Scheme 1. Coordination modes for the ligand dapmp.

mass spectra were obtained with a JEOL HX-110 HF double focusing spectrometer operating in the positive ion detection mode. TGA analyses were recorded with a NETZSCH STA 449C rnicroanalyzer in an atmosphere of nitrogen at a heating rate of $5{ }^{\circ} \mathrm{C} \mathrm{min}^{-1}$.

\subsection{Synthesis of 2,4-di(2-aminopyridine)-6-methylpyrimidine (dapmp, 1)}

2,4-Dichloro-6-methylpyrimidine $(5.0 \mathrm{~g}, 31.1 \mathrm{mmol})$ and 2-aminopyridine $(6.0 \mathrm{~g}, 72.9 \mathrm{mmol})$ were added to $100 \mathrm{ml}$ dry benzene in a $200 \mathrm{ml}$ flask. Then BuOK $(14.3 \mathrm{~g}, \quad 127.7 \mathrm{mmol})$ and tris(dibenzylideneacetone)dipalladium $\left(\mathrm{Pd}_{2}(\mathrm{dba})_{3}\right)(2.0 \mathrm{~g}, 2.2 \mathrm{mmol})$ were added to the solution under nitrogen. The resulting solution was stirred for $148 \mathrm{~h}$ under reflux. The product was filtered and washed three times each with methanol and water. Compound $\mathbf{1}$ was obtained as a white powder in $64 \%$ yield $(8.7 \mathrm{~g})$. Anal. Calc. for $\mathrm{C}_{15} \mathrm{H}_{14} \mathrm{~N}_{6}$ : C, 64.47; $\mathrm{H}$, 5.070: N, 30.18 .

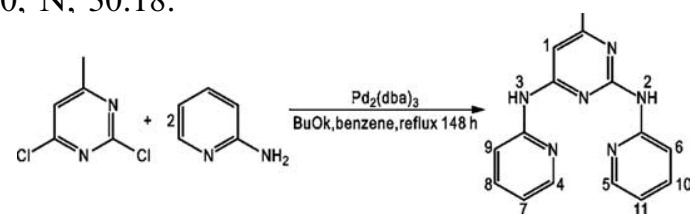

Found: C, 64.46; H, 4.891; N, 29.56\%. IR (KBr, $\left.\mathrm{cm}^{-1}\right): \quad v=3176(\mathrm{w}), \quad 3028(\mathrm{w}), \quad 1599(\mathrm{~s}), \quad 1569(\mathrm{~m})$, 1505(m), 1466(m), 1425(s), 1358(s), 1299(m), 1248(vw), 1218(w), 1149(w), 1048(w), 987(m), 773(s), 709(m), 617(vw). MS (FAB) $m / z$ (\%) 279.2 (dapmp). ${ }^{1} \mathrm{H}$ NMR $\left(\mathrm{CDCl}_{3}\right): \delta=7.14(\mathrm{~s}, 1 \mathrm{H}, 1-\mathrm{H}), 9.63(\mathrm{~s}, 1 \mathrm{H}, 2-\mathrm{H}), 9.44(\mathrm{~s}$, $1 \mathrm{H}, 3-\mathrm{H}), 8.37\left(\mathrm{~d}, 1 \mathrm{H},{ }^{3} J=4.8 \mathrm{~Hz}, 4-\mathrm{H}\right), 8.37(\mathrm{~d}, 1 \mathrm{H}$, $\left.{ }^{3} J=4.8 \mathrm{~Hz}, \quad 5-\mathrm{H}\right), 8.33\left(\mathrm{~d}, 1 \mathrm{H},{ }^{3} J=3.6 \mathrm{~Hz} 6-\mathrm{H}\right)$, $6.92\left(\mathrm{dt}, 1 \mathrm{H},{ }^{3} J=7.6 \mathrm{~Hz},{ }^{4} J=3.6 \mathrm{~Hz}, 7-\mathrm{H}\right), 6.93(\mathrm{dt}$, $\left.1 \mathrm{H},{ }^{3} J=7.6 \mathrm{~Hz},{ }^{4} J=2.4 \mathrm{~Hz}, 8-\mathrm{H}\right), 7.37(\mathrm{~d}, 1 \mathrm{H}, 9-\mathrm{H})$, $7.68\left(\mathrm{dt}, \quad 1 \mathrm{H}, \quad{ }^{3} J=7.8 \quad \mathrm{~Hz}, \quad{ }^{4} J=2.0 \quad \mathrm{~Hz}, \quad 10-\mathrm{H}\right)$, $7.62\left(\mathrm{dt},{ }^{4} J=2.0 \mathrm{~Hz}, 11-\mathrm{H}\right), 2.42\left(\mathrm{~s}, 3 \mathrm{H}, \mathrm{CH}_{3}\right) \mathrm{ppm}$.

\subsection{Synthesis of [Cu (dapmp) $\left.\mathrm{Cl}_{2}\right]$ (2)}

A solution of the ligand dapmp (61.2 $\mathrm{mg}, 0.22 \mathrm{mmol})$ and $\mathrm{CuCl}_{2} \cdot 2 \mathrm{H}_{2} \mathrm{O}(34.1 \mathrm{mg}, 0.2 \mathrm{mmol})$ in methanol (15 $\mathrm{ml})$ were mixed together and stirred for $3 \mathrm{~h}$. The green solution was filtered. Suitable X-ray quality crystals were obtained by slow evaporation of this green solution. Yield: $42 \%$. Anal. Calc. for $\left[\mathrm{Cu}\left(\mathrm{C}_{15} \mathrm{H}_{14} \mathrm{~N}_{6}\right) \mathrm{Cl}_{2}\right]$ : C, 43.65; H, 3.419; N, 20.36. Found: C, 43.46; H, $3.485 ; \mathrm{N}, 20.12 \%$.

\subsection{Synthesis of $\left[\mathrm{Cu}(\right.$ dapmp $\left.)\left(\mathrm{CH}_{3} \mathrm{COO}\right)_{2}\right] \cdot \mathrm{H}_{2} \mathrm{O}(3)$}

A solution of the ligand dapmp $(61.2 \mathrm{mg}, 0.22 \mathrm{mmol})$ and $\mathrm{Cu}\left(\mathrm{CH}_{3} \mathrm{COO}\right)_{2} \cdot \mathrm{H}_{2} \mathrm{O}(39.9 \mathrm{mg}, 0.2 \mathrm{mmol})$ in methanol $(15 \mathrm{ml})$ were mixed together and stirred for $3 \mathrm{~h}$. The blue-green solution obtained was filtered, from which $\mathrm{X}$-ray quality crystals were obtained by slow evapora- 
Table 1

Data collection and processing parameters for dapmp (1), $\left[\mathrm{Cu}(\right.$ dapmp $\left.) \mathrm{Cl}_{2}\right](\mathbf{2})$ and $\left[\mathrm{Cu}(\right.$ dapmp $\left.)\left(\mathrm{CH}_{3} \mathrm{COO}\right)_{2}\right] \cdot \mathrm{H}_{2} \mathrm{O}(\mathbf{3})$

\begin{tabular}{|c|c|c|c|}
\hline & (1) & (2) & (3) \\
\hline Empirical formula & $\mathrm{C}_{15} \mathrm{H}_{14} \mathrm{~N}_{6}$ & $\mathrm{C}_{15} \mathrm{H}_{14} \mathrm{Cl}_{2} \mathrm{CuN}_{6}$ & $\mathrm{C}_{19} \mathrm{H}_{22} \mathrm{CuN}_{6} \mathrm{O}_{5}$ \\
\hline Formula weight & 278.32 & 412.76 & 477.97 \\
\hline Temperature (K) & $295(2)$ & $150(1)$ & $150(1)$ \\
\hline Wavelength $(\AA)$ & 0.71073 & 0.71073 & 0.71073 \\
\hline Crystal system & monoclinic & monoclinic & monoclinic \\
\hline Space group & $P 2_{1} / n$ & $P 2_{1} / c$ & $P 2_{1} / n$ \\
\hline$a(\AA)$ & $9.8006(4)$ & $10.2639(2)$ & $11.2417(5)$ \\
\hline$b(\AA)$ & $16.2106(6)$ & $18.8819(4)$ & $11.6485(5)$ \\
\hline$c(\AA)$ & $17.2988(7)$ & $8.6769(2)$ & $15.5540(8)$ \\
\hline$\beta\left(^{\circ}\right)$ & $91.539(1)$ & $105.233(1)$ & $101.856(1)$ \\
\hline Volume $\left(\AA^{3}\right)$ & $2747.3(2)$ & $1622.52(6)$ & $1996.9(2)$ \\
\hline$Z$ & 8 & 4 & 4 \\
\hline$D_{\text {calc }}\left(\mathrm{g} / \mathrm{cm}^{3}\right)$ & 1.346 & 1.690 & 1.590 \\
\hline Absorption coefficient $\left(\mathrm{nm}^{-1}\right)$ & 0.087 & 1.685 & 1.140 \\
\hline$F(000)$ & 1168 & 836 & 988 \\
\hline Crystal size (mm) & $0.20 \times 0.12 \times 0.10$ & $0.20 \times 0.15 \times 0.12$ & $0.12 \times 0.12 \times 0.08$ \\
\hline$\theta$ range for data collection $\left({ }^{\circ}\right)$ & $1.72-27.50$ & $2.06-27.50$ & $2.05-27.50$ \\
\hline Limiting indices & $\begin{array}{l}-12 \leqslant h \leqslant 12,-21 \leqslant k \leqslant 21 \\
-22 \leqslant l \leqslant 18\end{array}$ & $\begin{array}{l}-11 \leqslant h \leqslant 13,-24 \leqslant k \leqslant 23 \\
-11 \leqslant l \leqslant 10\end{array}$ & $\begin{array}{l}-13 \leqslant h \leqslant 14,-14 \leqslant k \leqslant 15 \\
-20 \leqslant l \leqslant 20\end{array}$ \\
\hline Reflections collected & 21870 & 17432 & 19501 \\
\hline Independent reflections & 6307 & 3716 & 4579 \\
\hline Absorption correction & semi-empirical & semi-empirical & semi-empirical \\
\hline Maximum and minimum transmission & 0.9914 and 0.9828 & 0.827 and 0.707 & 0.9143 and 0.8753 \\
\hline Refinement method & full-matrix least-squares on $F^{2}$ & full-matrix least-squares on $F^{2}$ & full-matrix least-squares on $F^{2}$ \\
\hline Data/restraints/parameters & $6307 / 0 / 379$ & $3716 / 0 / 218$ & $4579 / 0 / 288$ \\
\hline Goodness-of-fit on $F^{2}$ & 1.026 & 1.128 & 1.068 \\
\hline$R_{1}, w R_{2}[I>2 \sigma(I)]$ & $0.0667,0.1503$ & $0.0481,0.1129$ & $0.0443,0.1042$ \\
\hline$R_{1}, w R_{2}$ (all data) & $0.1532,0.1861$ & $0.0817,0.1440$ & $0.0584,0.1108$ \\
\hline Largest difference peak and hole $\left(\mathrm{e} \AA^{-3}\right)$ & 0.243 and -0.253 & 1.011 and -0.826 & 0.492 and -0.369 \\
\hline
\end{tabular}
$R=\sum|| F_{\mathrm{o}}|-| F_{\mathrm{c}}|| / \sum\left|F_{\mathrm{o}}\right| ; w R_{2}=\left[\sum\left[w\left(F_{\mathrm{o}}^{2}-F_{\mathrm{c}}^{2}\right)^{2}\right] / \sum\left[\left(F_{\mathrm{o}}^{2}\right)^{2}\right]\right]^{1 / 2}$.

Table 2

Selected bond lengths $(\AA)$ and bond angles $\left(^{\circ}\right)$ of dapmp (1), $\mathrm{Cu}($ dapmp$) \mathrm{Cl}_{2}(\mathbf{2})$ and $\left[\mathrm{Cu}(\right.$ dapmp$\left.)\left(\mathrm{CH}_{3} \mathrm{COO}\right)_{2}\right] \cdot \mathrm{H}_{2} \mathrm{O}(\mathbf{3})$

\begin{tabular}{|c|c|c|c|c|c|}
\hline \multirow{2}{*}{$\frac{\text { Dapmp (1) }}{\text { Bond lengths }}$} & & \multicolumn{2}{|l|}{$\mathrm{Cu}($ dapmp$) \mathrm{Cl}_{2}(2)$} & \multicolumn{2}{|c|}{$\left[\mathrm{Cu}(\right.$ dapmp $\left.)\left(\mathrm{CH}_{3} \mathrm{COO}\right)_{2}\right] \cdot \mathrm{H}_{2} \mathrm{O}(3)$} \\
\hline & & & & & \\
\hline $\mathrm{N}(1)-\mathrm{C}(1)$ & $1.333(4)$ & $\mathrm{Cu}-\mathrm{N}(5)$ & $1.9666(3)$ & $\mathrm{Cu}-\mathrm{N}(5)$ & $1.978(2)$ \\
\hline$N(1)-C(5)$ & $1.341(3)$ & $\mathrm{Cu}-\mathrm{N}(3)$ & $2.071(3)$ & $\mathrm{Cu}-\mathrm{N}(3)$ & $2.067(2)$ \\
\hline$N(2)-C(6)$ & $1.375(3)$ & $\mathrm{Cu}-\mathrm{N}(1)$ & $1.974(3)$ & $\mathrm{Cu}-\mathrm{N}(1)$ & $1.975(2)$ \\
\hline $\mathrm{N}(2)-\mathrm{C}(5)$ & $1.384(3)$ & $\mathrm{Cu}-\mathrm{Cl}(1)$ & $2.369(1)$ & $\mathrm{Cu}-\mathrm{O}(3)$ & $2.162(2)$ \\
\hline$N(6)-C(7)$ & $1.350(4)$ & $\mathrm{Cu}-\mathrm{Cl}(2)$ & $2.417(1)$ & $\mathrm{Cu}-\mathrm{O}(1)$ & $1.996(2)$ \\
\hline $\mathrm{N}(6)-\mathrm{C}(6)$ & $1.359(3)$ & $\mathrm{N}(1)-\mathrm{C}(1)$ & $1.358(5)$ & $\mathrm{O}(1)-\mathrm{C}(16)$ & $1.267(3)$ \\
\hline $\mathrm{N}(12)-\mathrm{C}(21)$ & $1.367(4)$ & $\mathrm{N}(1)-\mathrm{C}(5)$ & $1.327(5)$ & $\mathrm{O}(2)-\mathrm{C}(16)$ & $1.244(3)$ \\
\hline $\mathrm{N}(12)-\mathrm{C}(22)$ & $1.372(4)$ & $\mathrm{N}(3)-\mathrm{C}(9)$ & $1.361(4)$ & $\mathrm{O}(3)-\mathrm{C}(18)$ & $1.273(3)$ \\
\hline $\mathrm{N}\left(12^{\prime}\right)-\mathrm{C}(24)$ & $1.354(4)$ & $\mathrm{N}(3)-\mathrm{C}(6)$ & $1.352(5)$ & $\mathrm{O}(4)-\mathrm{C}(18)$ & $1.242(3)$ \\
\hline $\mathrm{N}\left(12^{\prime}\right)-\mathrm{C}(22)$ & $1.358(4)$ & $\mathrm{N}(5)-\mathrm{C}(14)$ & $1.347(5)$ & $\mathrm{N}(3)-\mathrm{C}(6)$ & $1.362(3)$ \\
\hline $\mathrm{C}(7)-\mathrm{C}(8)$ & $1.362(4)$ & $\mathrm{N}(5)-\mathrm{C}(10)$ & $1.335(5)$ & $\mathrm{N}(6)-\mathrm{C}(6)$ & $1.343(3)$ \\
\hline $\mathrm{C}(8)-\mathrm{C}(9)$ & $1.369(4)$ & $\mathrm{N}(6)-\mathrm{C}(7)$ & $1.358(5)$ & $\mathrm{N}(3)-\mathrm{C}(9)$ & $1.352(3)$ \\
\hline \multicolumn{6}{|l|}{ Bond angles } \\
\hline $\mathrm{C}(4)-\mathrm{C}(5)-\mathrm{N}(2)$ & $124.8(3)$ & $\mathrm{N}(5)-\mathrm{Cu}-\mathrm{N}(1)$ & $172.3(1)$ & $\mathrm{N}(5)-\mathrm{Cu}-\mathrm{N}(1)$ & $172.84(9)$ \\
\hline $\mathrm{C}(6)-\mathrm{N}(2)-\mathrm{C}(5)$ & $129.9(2)$ & $\mathrm{N}(1)-\mathrm{Cu}-\mathrm{N}(3)$ & 94.1(1) & $\mathrm{N}(5)-\mathrm{Cu}-\mathrm{O}(1)$ & $89.80(9)$ \\
\hline $\mathrm{N}(2)-\mathrm{C}(6)-\mathrm{N}(3)$ & $119.9(2)$ & $\mathrm{N}(5)-\mathrm{Cu}-\mathrm{N}(3)$ & $93.6(1)$ & $\mathrm{N}(5)-\mathrm{Cu}-\mathrm{N}(3)$ & $93.27(9)$ \\
\hline $\mathrm{N}(3)-\mathrm{C}(9)-\mathrm{N}(4)$ & $118.9(3)$ & $\mathrm{N}(1)-\mathrm{Cu}-\mathrm{Cl}(1)$ & $88.99(9)$ & $\mathrm{N}(1)-\mathrm{Cu}-\mathrm{O}(3)$ & $88.62(8)$ \\
\hline $\mathrm{C}(9)-\mathrm{N}(4)-\mathrm{C}(10)$ & 128.3(2) & $\mathrm{N}(5)-\mathrm{Cu}-\mathrm{Cl}(1)$ & $88.13(9)$ & $\mathrm{O}(1)-\mathrm{Cu}-\mathrm{O}(3)$ & $121.54(8)$ \\
\hline $\mathrm{N}(4)-\mathrm{C}(10)-\mathrm{C}(11)$ & $123.3(3)$ & $\mathrm{N}(5)-\mathrm{Cu}-\mathrm{Cl}(2)$ & $88.77(9)$ & $\mathrm{N}(3)-\mathrm{Cu}-\mathrm{O}(1)$ & $139.58(8)$ \\
\hline $\mathrm{C}(19)-\mathrm{C}(20)-\mathrm{N}(8)$ & $124.1(3)$ & $\mathrm{N}(1)-\mathrm{Cu}-\mathrm{Cl}(2)$ & $88.46(9)$ & $\mathrm{N}(1)-\mathrm{Cu}-\mathrm{O}(1)$ & $88.24(8)$ \\
\hline $\mathrm{C}(20)-\mathrm{N}(8)-\mathrm{C}(21)$ & $130.9(3)$ & $\mathrm{N}(3)-\mathrm{Cu}-\mathrm{Cl}(2)$ & $107.48(8)$ & $\mathrm{N}(1)-\mathrm{Cu}-\mathrm{N}(3)$ & $92.68(9)$ \\
\hline $\mathrm{N}(8)-\mathrm{C}(21)-\mathrm{N}(9)$ & 119.7(3) & $\mathrm{N}(3)-\mathrm{Cu}-\mathrm{Cl}(1)$ & $115.64(8)$ & $\mathrm{N}(5)-\mathrm{Cu}-\mathrm{O}(3)$ & $86.53(8)$ \\
\hline $\mathrm{C}(24)-\mathrm{N}(10)-\mathrm{C}(25)$ & $129.1(2)$ & $\mathrm{Cl}(1)-\mathrm{Cu}-\mathrm{Cl}(2)$ & $136.88(4)$ & $\mathrm{N}(3)-\mathrm{Cu}-\mathrm{O}(3)$ & $98.88(8)$ \\
\hline
\end{tabular}


tion. Yield: $51 \%$. Anal. Calc. for $\left[\mathrm{Cu}\left(\mathrm{C}_{15} \mathrm{H}_{14} \mathrm{~N}_{6}\right)\left(\mathrm{CH}_{3-}\right.\right.$ $\left.\mathrm{OO})_{2}\right] \cdot \mathrm{H}_{2} \mathrm{O}: \mathrm{C}, 47.75 ; \mathrm{H}, 4.640 ; \mathrm{N}, 17.58$. Found: C, 47.92; H, 4.478; N, 17.71\%.

\subsection{Crystal structure determination}

$\mathrm{X}$-ray diffraction data were collected with graphitemonochromated Mo $\mathrm{K} \alpha$ radiation $\lambda=0.71073 \AA$ ) on a BRUKER SMART APEXCCD diffractometer for compound $\mathbf{1}$, on a NONIUS KaCCD diffractometer for complex 2 and on a BRUKER SMART APEXCCD diffractometer for complex 3 . The structures were solved by direct methods with the SHELXL-93 [8] program and refined by full-matrix least-squares methods on $F^{2}$ with SHELXTL-PC V 5.03 [9]. Crystal data and structure refinement details are summarized in Table 1 . Selected bond lengths and bond angles are given in Table 2 .

\section{Results and discussion}

\subsection{Description of structures}

Fig. 1 shows the molecular packing of compound $\mathbf{1}$. It can be seen that the ligand dapmp forms zigzag chains in the solid state, and the molecules are held together by a series of donor-acceptor (DA) double hydrogen bonds. Each molecule with the all-anti conformation is linked via two hydrogen bonds $(\mathrm{N}(1) \cdots \mathrm{N}(10) 3.104 \AA$, $\mathrm{N}(2) \cdots \mathrm{N}(11) \quad 3.107 \AA$ ) with a centrosymmetrically related counterpart to form a dimer as depicted in Fig. 1. The structural characterization of such hydrogen-bonded dimeric compounds linked by self complementary donor-acceptor groups is well documented in organic chemistry [10-13]. The adjacent dapmp dimer units are interlanced and are connected by two hydrogen bonds $(\mathrm{N}(7) \cdots \mathrm{N}(4) \quad 3.147 \AA, \mathrm{N}(8) \cdots \mathrm{N}(5) \quad 3.189 \AA)$, forming a one-dimensional supermolecular compound along the $c$ axis (Fig. 1).

The bond length of $\mathrm{N}(6)-\mathrm{C}(7) 1.350(4) \AA$ is shorter than that of $\mathrm{N}(12 \mathrm{C})-\mathrm{C}(22 \mathrm{~B})(1.358(4) \AA)$ while the angle of $\mathrm{C}(5)-\mathrm{N}(2)-\mathrm{C}(6)\left(129.9(2)^{\circ}\right)$ is similar to that of $\mathrm{C}(9)$ $\mathrm{N}(4)-\mathrm{C}(10)\left(128.3(2)^{\circ}\right)$. The three rings of the dapmp li-

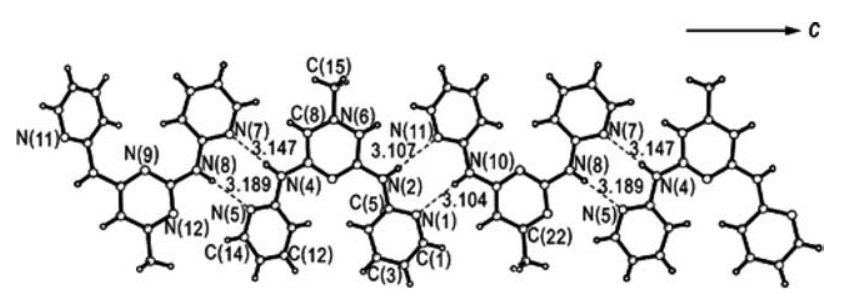

Fig. 1. An ORTEP diagram of dapmp (1), showing the interactions among the ligands. Thermal ellipsoids are at the $50 \%$ probability level. gand are each planar and the dihedral angle between each pair of neighboring rings is $144.7^{\circ}$ and $163.1^{\circ}$.

The crystal structure of complex 2 (Fig. 2) reveals that the coordination geometry around copper(II) is distorted trigonal bipyramidal with the monohelical dapmp ligand existing in an all-anti configuration. The equatorial sites consists of $\mathrm{N}(3)$, which comes from the pyrimidyl ring of the tridentate dapmp, and two Cl-donors, and the apical sites are occupied by $\mathrm{N}(1)$ and $\mathrm{N}(5)$ atoms of the pyridal rings. The bond angles $\mathrm{Cl}(1)-\mathrm{Cu}-\mathrm{Cl}(2)$ $\left(136.88(4)^{\circ}\right), \mathrm{N}(3)-\mathrm{Cu}-\mathrm{Cl}(1)\left(115.64(8)^{\circ}\right)$ and $\mathrm{N}(3)-\mathrm{Cu}-$ $\mathrm{Cl}(2)\left(107.48(8)^{\circ}\right)$ sum up to $360^{\circ}$ and the $\mathrm{Cu}(\mathrm{II})$ atom lies in the equatorial plane. The average $\mathrm{Cu}-\mathrm{N}$ bond length is observed to be $2.004 \AA$ while the $\mathrm{Cu}-\mathrm{Cl}$ bond length is $2.393 \AA$. The dihedral angle between the plane $1(\mathrm{Cu}, \mathrm{Cl}(1), \mathrm{Cl}(2), \mathrm{N}(3))$ and the plane $2(\mathrm{~N}(3), \mathrm{N}(6)$, $\mathrm{C}(6), \mathrm{C}(7), \mathrm{C}(8), \mathrm{C}(9))$ is $88.9^{\circ}$. The mononuclear unit is connected via two $\mathrm{N}-\mathrm{H} \cdots \mathrm{Cl}$ hydrogen bonds (N(4B) ‥ Cl(2A) $3.225 \AA, \mathrm{Cl}(2 \mathrm{~B}) \cdots \mathrm{N}(4 \mathrm{~A}) 3.225 \AA$ ) with a centrosymmetrically related counterpart to form a dimer as depicted in Fig. 3. The structural characterization of such hydrogen-bonded dimeric compounds linked by self complementary donor/acceptor groups is scarce for inorganic compounds. We are aware of only a few transition metal carboxylates of, e.g. zinc [14] and platinum [15] displaying pairs of symmetric $\mathrm{C}=\mathrm{O} \cdots \mathrm{H}-\mathrm{N}$ bridges, while here copper displays pairs of symmetric $\mathrm{Cl} \cdots \mathrm{H}-\mathrm{N}$ bridges. The dimer is linked via another two $\mathrm{Cl} \cdots \mathrm{H}-\mathrm{N}$ bridges to form a one-dimensional supermolecular chain along the $c$ axis (Fig. 3).

Complex 3 has the same coordination configuration as $\mathbf{2}$. The copper(II) atom is 5-coordinated with three $\mathrm{N}$ atoms from the ligand dapmp and two monodentate $\mathrm{CH}_{3} \mathrm{COO}^{-1}$ ligands in an approximately trigonal bipyramidal environment (Fig. 4). The basal plane is formed by two $\mathrm{O}$ atoms from $\mathrm{CH}_{3} \mathrm{COO}^{-1}$ and one $\mathrm{N}$ atom of the

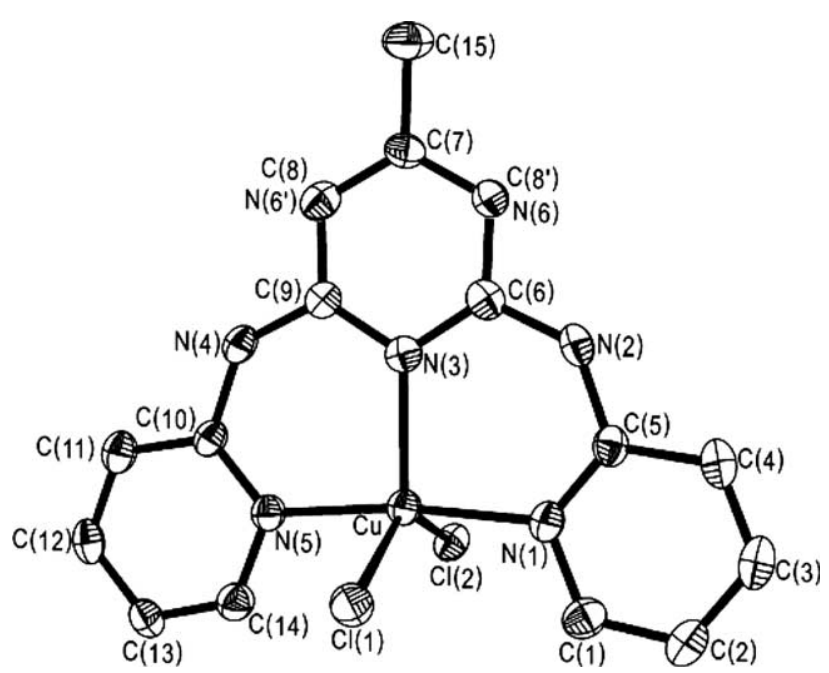

Fig. 2. The ORTEP drawing of $\mathrm{Cu}(\mathrm{dapmp}) \mathrm{Cl}_{2}$ (2). Thermal ellipsoids are drawn at the $50 \%$ probability level. 


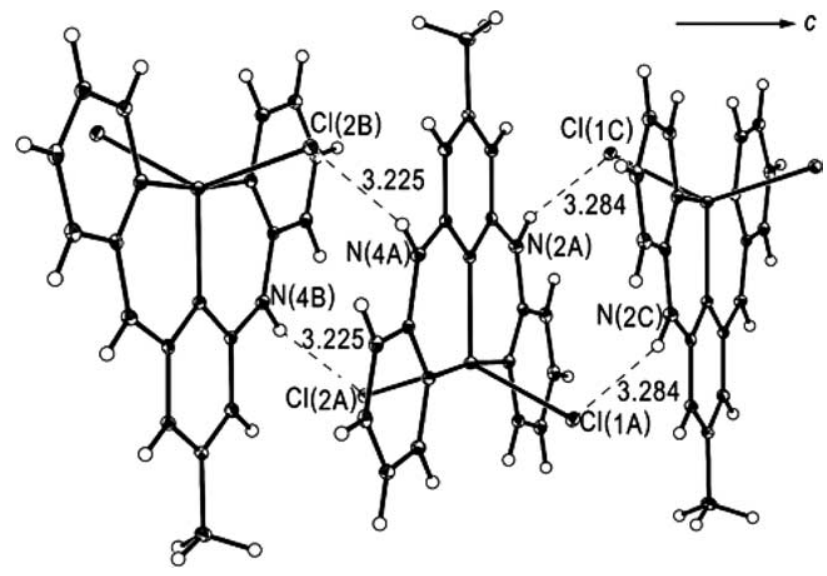

Fig. 3. The one-dimensional chains structure of $\mathrm{Cu}(\mathrm{dapmp}) \mathrm{Cl}_{2}(2$ formed by hydrogen-bonding interactions (dashed lines).

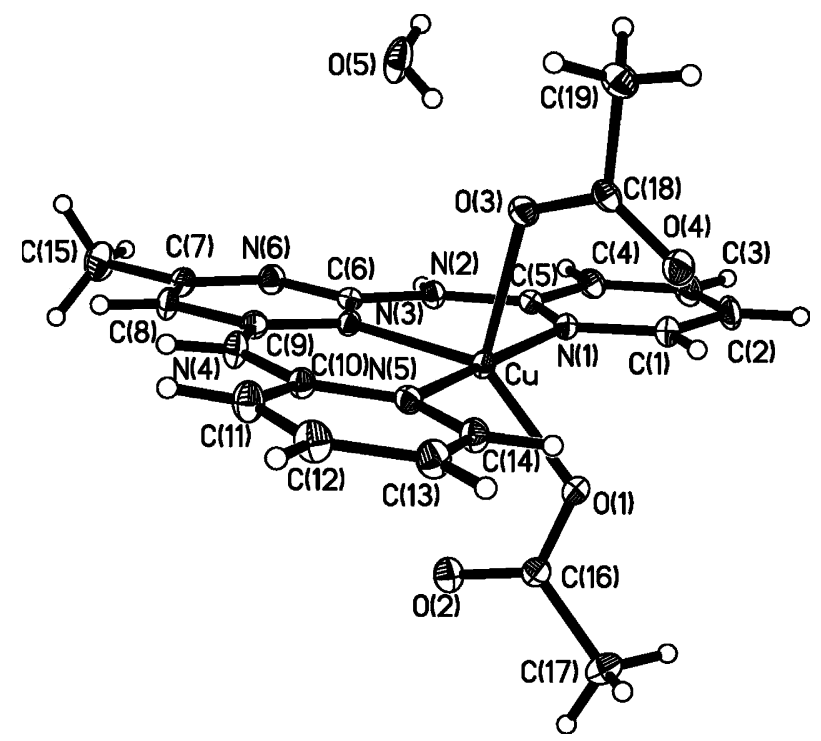

Fig. 4. The ORTEP drawing of $\left[\mathrm{Cu}(\right.$ dapmp $)\left(\mathrm{CH}_{3}\right] \cdot \mathrm{H}_{2} \mathrm{O}(3)$. Thermal ellipsoids are drawn at the $50 \%$ probability level.

central pyrimidine, which is indicated by bond angle summation $\left(360^{\circ}\right)$ of $\mathrm{O}(1)-\mathrm{Cu}-\mathrm{O}(3)\left(121.54(8)^{\circ}\right), \mathrm{N}(3)-$ $\mathrm{Cu}-\mathrm{O}(1)\left(139.58(8)^{\circ}\right)$ and $\mathrm{N}(3)-\mathrm{Cu}-\mathrm{O}(3)\left(98.88(8)^{\circ}\right)$. The apical positions are occupied by two $\mathrm{N}$ atoms of terminal pyridine groups $\left(\mathrm{N}(1)-\mathrm{Cu}-\mathrm{N}(5) 172.84(9)^{\circ}\right)$. The corresponding $\mathrm{Cu}-\mathrm{N}_{(\mathrm{dapmp})}$ and $\mathrm{Cu}-\mathrm{O}_{\left(\mathrm{CH}_{3} \mathrm{COO}^{-}\right)}$distances have the same magnitude, ranging from 1.975(2) to $2.067(2) \AA$. Within the acetate groups the $\mathrm{C}-\mathrm{O}$ distances are greater for the strongly coordinated $\mathrm{O}$ atoms $\mathrm{C}(18)-\mathrm{O}(3)$ and $\mathrm{C}(16)-\mathrm{O}(1)$ (average $1.270 \AA$ ) than for the non-coordinated $\mathrm{O}$ atoms (average $1.243 \AA$ ). Intermolecular bonding of $\mathrm{O}(2)$ results in an intermediate $\mathrm{C}(16)-\mathrm{O}(2)$ distance $(1.244 \AA)$. Both $\mathrm{Cu}-\mathrm{N}$ bond lengths are typical of those found for the 5-coordinate $\mathrm{Cu}(\mathrm{II})-\mu$ pmea analogues [16]. Buckling of the tridentate dapmp ligand produces a dihedral angle between the two pyridyl rings of $10.5^{\circ}$. The $\mathrm{Cu}-\mathrm{O}(3)$ bond has the longest distance $(2.162(2) \AA)$ in the 5-coordinated unit. The average
$\mathrm{Cu}-\mathrm{N}$ bond length is observed to be $2.006 \AA$, which is similar to the average $\mathrm{Cu}-\mathrm{N}$ bond length of 2 . The dihedral angle $\left(84.6^{\circ}\right)$ between the plane $(\mathrm{Cu}, \mathrm{O}(1), \mathrm{O}(3)$, $\mathrm{N}(3)$ ) and the pyrimidine ring plane is smaller than that of 2 between the plane $(\mathrm{Cu}, \mathrm{Cl}(1), \mathrm{Cl}(2), \mathrm{N}(3))$ and the plane of the pyrimidine ring $\left(88.9^{\circ}\right)$.

The mononuclear units are bridged by two $\mathrm{H}_{2} \mathrm{O}$ molecules via four hydrogen bonds to form a dimeric unit (Fig. 5). On the other hand, via two hydrogen bondings $\left(\mathrm{O}_{\text {uncoord }} \cdots \mathrm{N}(\mathrm{H}), 2.806 \AA\right)$, adjacent dimers are interconnected, giving rise to a one-dimensional supermolecular chain along the crystallographic $a$ axis. It is worthy of note that the $\mathrm{H}_{2} \mathrm{O}$ molecule binds the other uncoordinated $\mathrm{O}$ atom of $\mathrm{CH}_{3} \mathrm{COO}^{-1}$ by hydrogen bonds $(\mathrm{O}(5) \cdots \mathrm{O}(4), 2.744 \AA)$ in the $b-c$ plane, and the neighboring chains are extended into a three-dimensional supermolecular structure.

\subsection{Spectroscopic properties}

The IR spectra of the complexes exhibit several characteristic strong bonds. In complex $\mathbf{2}$, the bands around 1598 and $1569 \mathrm{~cm}^{-1}$ in ligand dapmp (1), attributed to the $\mathrm{C}=\mathrm{N}$ grouping, are shifted to 1651 and $1588 \mathrm{~cm}^{-1}$, respectively, confirming the involvement of the ligand dapmp (1) in the copper complexation. In complex $\mathbf{3}$, the corresponding bands are shifted to 1684 and 1642 $\mathrm{cm}^{-1}$. The bands corresponding to $v_{\mathrm{as}}(\mathrm{COO})$ and $v_{\text {sym }}(-$ COO) are at 1590 and $1397 \mathrm{~cm}^{-1}[17,18]$. The $\Delta v$ of the complex are $193 \mathrm{~cm}^{-1}$ more than the corresponding values for $\mathrm{CH}_{3} \mathrm{COONa}\left(164 \mathrm{~cm}^{-1}\right)$, indicating that the $\mathrm{CH}_{3} \mathrm{COO}^{-}$group behaves as a monodentate ligand [18]. Other obsorption peaks can also be assigned to the ligand dapmp (1). These are in good agreement with the crystallographic results. The electronic spectra of the two complexes in methanol at ambient temperature were measured. On the basis of high extinction coefficient, the bands at 49505, 46296 and $47393 \mathrm{~cm}^{-1}$ can be ascribed to a $\pi-\pi$ transition of the ligand in $\mathbf{1}, \mathbf{2}$ and $\mathbf{3}$, respectively. There are two bands $39370 \mathrm{~cm}^{-1}$ (complex 2)

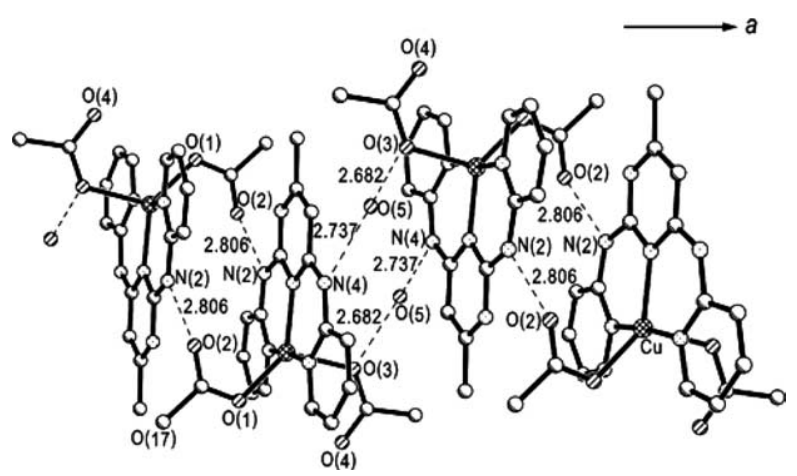

Fig. 5. The molecule packing of $\left[\mathrm{Cu}(\right.$ dapmp $)\left(\mathrm{CH}_{3}\right] \cdot \mathrm{H}_{2} \mathrm{O}$ (3) formed by hydrogen-bonding interactions (dashed lines). For the interest of clarity, the hydrogen atoms are omitted. 
and $39063 \mathrm{~cm}^{-1}$ (complex 3) corresponding to a metalligand charge transfer transition. The shoulder band $32573 \mathrm{~cm}^{-1}$ is due to the $\mathrm{d}-\mathrm{d}$ transition in $\mathbf{2}$ and the band $32468 \mathrm{~cm}^{-1}$ due to the $\mathrm{d}-\mathrm{d}$ transition in $\mathbf{3}$. In addition, there is a weak unresolved shoulder at $30581 \mathrm{~cm}^{-1}$ in $\mathbf{1}$.

\subsection{Thermogravimetric analysis}

Thermogravimetric analysis of complex $\mathbf{3}$ was carried out to examine its thermal stability. The TGA curve shows that the first weight loss of $3.68 \%$, which occurs between 80 and $105{ }^{\circ} \mathrm{C}$, corresponds to the loss of an uncoordinated water molecule (calc.: 3.77\%). Further decomposition begins at $175{ }^{\circ} \mathrm{C}$ and ends at $560{ }^{\circ} \mathrm{C}$ with residue $\mathrm{CuO}$ in $17.5 \%$ yield (calc.: $16.6 \%$ ). Thermogravimetric analysis of complex $\mathbf{2}$ shows that the decomposition begins at $291{ }^{\circ} \mathrm{C}$ and ends at $690.2{ }^{\circ} \mathrm{C}$ with residue $\mathrm{CuO}$ in 20.2 yield (calc.: 19.4\%).

\section{Supplementary material}

Crystallographic data for the structural analysis have been deposited with the Cambridge Crystallographic Data Center, CCDC No. 236246 for compound 1, 236245 for compound 2 and 236244 for compound $\mathbf{3}$. Copies of this information may be obtained free of charge on application to CCDC, 12 Union Road, Cambridge CB2 1EZ, UK (fax: +44-1223-336-033; e-mail: deposit@ccdc.cam.ac.uk or http://www.ccdc.cam.ac.uk).

\section{Acknowledgments}

This work was supported by the National Natural Science Foundation of China 20471048 and IRAPOYT.

\section{References}

[1] N.F. Curtis, in: J.A. McCleverty, T.J.M. McCleverty (Eds.), Comprehensive Coordination Chemistry, 1st ed., Elsevier/Pergamon Press, Amsterdam, 2004, p. 447.

[2] J.A. McCleverty, M.D. Ward, in: J.A. McCleverty, T.J.M. McCleverty (Eds.), Comprehensive Coordination Chemistry, 1st ed., Elsevier/Pergamon Press, Amsterdam, 2004, p. 743 .

[3] M. FuJita, Y.J. Kwon, S. Washizu, K. Ogura, J. Am. Chem. Soc. 116 (1994) 1151.

[4] R.-G. Xiong, X.-Z. You, B.F. Abrahams, Z. Xue, C.-M. Che, Angew. Chem. Int. Ed. 40 (2001) 4422.

[5] D.M. Bassani, J.-M. Lehn, K. Froman, D. Fenske, Angew. Chem. Int. Ed. 41 (2002) 4041.

[6] N.L. Rosi, J. Eckert, M. Eddaoudi, D.T. Vodak, J. Kim, M. O'keeffe, O.M. Yaghi, Science 300 (2003) 1127.

[7] J.R. Galán-Mascarós, K.R. Dunbar, Angew. Chem. Int. Ed. 42 (2003) 2289.

[8] G.M. Sheldrick, ShelXL-93, Program for the Refinement of Crystal Structure, University of Göttingen, Göttingen, Germany, 1993.

[9] ShelXTL 5.03 (PC-version), Program Library for Structure Solution and Molecular Graphics, Siemens Analytical Instrument Division, Madison, WI, 1995.

[10] Z. Berkovitch-Yelli, L. Leiserowitz, J. Am. Chem. Soc. 102 (1980) 7677.

[11] A.T. Hagler, E. Huler, S. Lifson, J. Am. Chem. Soc. 96 (1974) 5319.

[12] A. Kvick, S.S. Booles, Acta Crystallogr., Sect. B 28 (1972) 3405.

[13] M. Simard, D. Su, J.D. Wuest, J. Am. Chem. Soc. 113 (1991) 4696.

[14] N. Rodier, R. Ceolin, M. Plat, H. Zumbihl, Acta Crystallogr., Sect. C 46 (1990) 324.

[15] A.D. Burrows, D.M.P. Mingos, A.J.P. White, D.J.J. Williams., J. Chem. Soc., Dalton Trans. (1996) 3805.

[16] K.-Y. Choi, Y.-M. Jeon, H. Ryu, J.-J. Oh, H.-H. Lim, M.-W. Kim, Polyhedron 23 (2004) 903.

[17] K. Nakamoto, Infrared and Raman Spectra of Inorganic and Coordination Compounds, 4th ed., Wiley, New York, 1986.

[18] G.B. Deacon, R.J. Phillips, Coord. Chem. Rev. 33 (1980) 227. 